\title{
IMPACT OF THE RESEARCH CONDITIONS ON THE ACCURACY OF THE DESIGNATION OF HIGH PERFORMANCE CONCRETE STRENGTH PARAMETERS
}

\author{
DANIEL WALACH ${ }^{1}$
}

\begin{abstract}
The article presents research results of the strength parameters of HPC achieved in various research conditions. The research was carried out on substantially different samples, both as to the size as the slenderness ratio. Moreover, the assessment of the effect of speed of a load on strength parameters as well as other factors which in a significant way show the difference in the strength values was made. For comparison, the results were also applied to the relations known in ordinary concrete.
\end{abstract}

Keywords: high performance concrete, civil engineering, strength parameters

\section{INTRODUCTION}

Technological Progress has caused a significant concrete production development. Possibility of realisation of many objects, including civil engineering, requires the use of concrete with more specialized properties and the use of mixtures of ever higher strength. High performance concrete which recently have wider application can be the answer to the growing civil engineering requirements [2].High performance concrete can be used in production of the underground excavation housing i.e. shafts, chambers and tunnels. Especially, in the case of the shaft housing, presently dominated by ordinary concrete, the introduction of high performance concrete can bring a total change in the approach to design and construction of excavations. Greater use of HPC, as for instance

\footnotetext{
${ }^{1}$ PhD., Eng., AGH University of Science and Technology, Al. Mickiewicza 30, 30-633 Kraków, Poland, e-mail: walach@Agh.edu.pl
} 
in shaft sinking, may result in decrease of housing thickness, its volume, volume of a breach and labour costs of concrete production.

The strength parameters of concrete substantially depend on conditions of the research. This applies to the size of the samples, and among many to the speed of a load. Those issues in relation to ordinary concrete are commonly known, but the research results of recently widely used high performance concrete are different than those of ordinary concretes. Knowledge of those issues may in a substantial way affect, among many, the interpretation of HPC diagnostic components.

The article shows the research results of HPC strength parameters determined in various conditions of the research. The research was carried out on substantially different samples both to the size and to the slenderness ratio. Moreover, the assessment of the impact of various factors, which result in differences in specified values of compressive strength of HPC, was carried out. For comparison, the results were also referred to the relations known in ordinary concretes.

\section{THE GENERAL DESCRIPTION OF THE RESEARCH}

The main purpose of the research was to obtain the results of experimental compressive strength of high performance concrete determined in various research conditions. Two concrete mixture compositions of the same content of coarse aggregate and w/c relation were used in the research. The first mixture was made of natural diabase aggregate and the second made of natural basalt aggregate. Table 1 shows the composition of concrete mixtures per $1 \mathrm{~m} 3$, and fig. 1 illustrates the results of sieve analysis carried out on the specific aggregates. Each mix was designed to strength class $\mathrm{C} 60 / 75$.
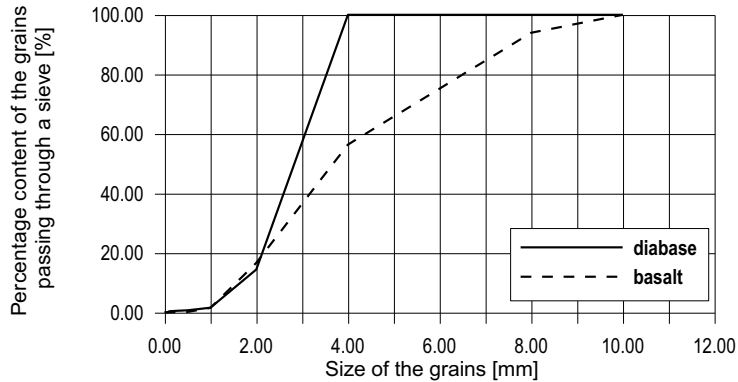

Fig. 1. Results of sieve analysis of used aggregates 
Table 1. Concrete mixture composition

\begin{tabular}{|c|c|}
\hline Component & {$\left[\mathrm{kg} / \mathrm{m}^{3}\right]$} \\
\hline Portland cement CEM I 42.5R & 500 \\
\hline Coarse aggregate(diabase/basalt) & 1150 \\
\hline Sand & 650 \\
\hline Microsilica & 18 \\
\hline Superplasticizers & 3.5 \\
\hline Water & 55 \\
\hline
\end{tabular}

Compressive strength fcm for the samples of tested concrete is as follows:

- $\quad$ cubes $15 \times 15 \times 15 \mathrm{~cm}$,

- $\quad$ cubes $10 \times 10 \times 10 \mathrm{~cm}$,

- $\quad$ cylinders $\varnothing 15 \times 30 \mathrm{~cm}$,

- $\quad$ cylinders $\varnothing 16 \times 16 \mathrm{~cm}$,

- $\quad$ cylinders $\varnothing 5.5 \times 11 \mathrm{~cm}$.

Markings on 5 samples were made for each experimental group with compressive strength determined in specific research conditions. All samples were taken after 28 days of maturing in the same climate conditions.

The research took into account the impact of slenderness ratio and the size of the samples as well as load application speed obtained for compressive strength of concrete tested.

\section{ANALYSIS OF THE RESEARCH RESULTS}

\subsection{IMPACT OF SLENDERNESS RATIO OF THE SAMPLES}

Research by standards on compressive strength was carried out on $\varnothing 15 \times 30$ cylindrical samples so samples with slenderness ratio 2. Sometimes samples with different proportions can be seen such as in core samples taken from existing constructions. In this case, conversion of obtained strength into strength by standards is necessary. The values of correction factors in relation to ordinary concrete are commonly known. However, in the case of HPC those factors can be different. In this respect the research was carried out on the cylindrical samples $\varnothing 15 \times 30 \mathrm{~cm}$ with ratio of $\mathrm{h} / \mathrm{d}=2$ and the cylindrical samples $\varnothing 16 \times 16 \mathrm{~cm}$ with ratio of $\mathrm{h} / \mathrm{d}=1$. The research results obtained for concrete made on diabase and basalt aggregates are shown in Table 2. 
Table 2. Research results of slenderness ratio for HPC samples

\begin{tabular}{|c|c|c|c|c|}
\hline \multirow{2}{*}{ Number } & $\begin{array}{c}\text { Compressive strength ratio for concrete } \\
\text { made on diabase aggregates [MPa] }\end{array}$ & \multicolumn{2}{c|}{$\begin{array}{c}\text { Compressive strength ratio for concrete } \\
\text { made on basalt aggregates [MPa] }\end{array}$} \\
\cline { 2 - 5 } & $h / d=2$ & $h / d=1$ & $h / d=2$ & $h / d=1$ \\
\hline 1 & 61.26 & 64.65 & 63.49 & 65.40 \\
\hline 2 & 63.01 & 71.06 & 67.64 & 67.46 \\
\hline 3 & 74.50 & 78.89 & 61.25 & 63.77 \\
\hline 4 & 58.63 & 75.43 & 65.83 & 62.57 \\
\hline 5 & 61.25 & 69.83 & 61.28 & 65.86 \\
\hline average & 63.73 & 71.97 & 63.90 & 2.05 \\
\hline $\begin{array}{l}\text { Standard } \\
\text { deviation }\end{array}$ & 6.22 & 5.45 & 2.81 & \\
\hline
\end{tabular}

a)

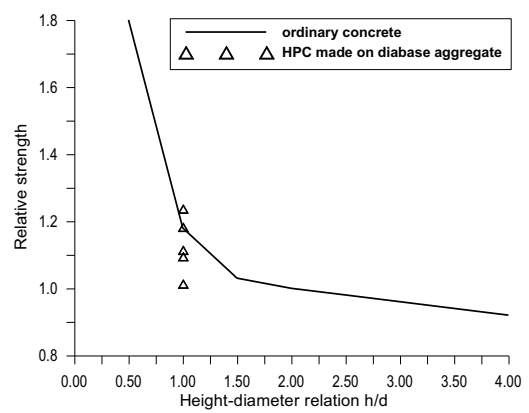

b)

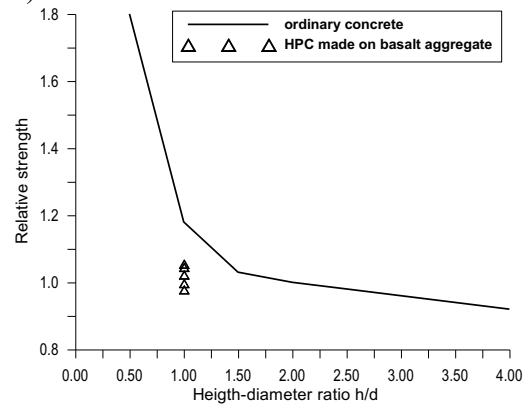

Fig. 2. Impact of height-diameter of the cylinder relation to the apparent strength of cylindrical sample made on ordinary concrete [4] and HPC tested: a) HPC made on diabase aggregate, b) HPC made on basalt aggregate.

a)

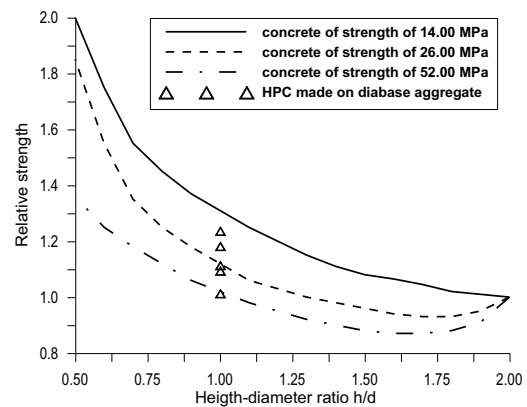

b)

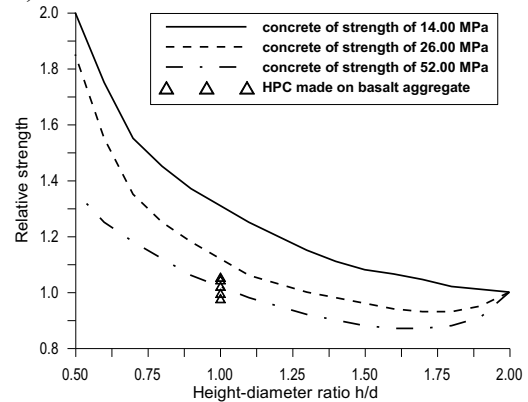

Fig. 3. Effect of height-diameter relation to the apparent strength of cylindrical samples made on ordinary concrete of various strength [3] and HPC tested: a) HPC made on diabase aggregate, b) HPC made on basalt aggregate. 
Obtained research results indicate that in the case of HPC differences of compressive strength determined for samples with various slenderness are substantially smaller than those for ordinary concrete. See fig. 2. As shown below, the relative strength was determined in relation to average strength determined on specific HPC samples with ratio of $h / d=2$. The obtained research results confirm the Murdock and Kesler theory [3]. The theory states that the values of correction factors also depend on values of the strength of concrete, see fig. 3. Thus, HPC strength is less susceptible to the changes of experimental samples and less depend on the shape of the sample. It can also be noticed that high performance concrete with average compressive strength at level of $63.73 \mathrm{MPa}$ and $63.90 \mathrm{MPa}$ in a satisfactory way fit into relations for higher-class concrete as defined by Murdock and Kesler. It follows that, for high performance concrete, the compressive strength determined on the samples with slenderness ratio less than 2 does not differ significantly from those determined on samples by standards with ratio of $\mathrm{h} / \mathrm{d}=2$. The results of study indicate, that dispersion of concrete made on diabase aggregates is higher than concrete based on basalt aggregates. It can be result of aggregate properties, as well as specifics of failure mechanism of HPC. In such case, the plane of destruction goes through both aggregates and matrix.

\subsection{EFFECT OF THE SIZE OF THE SAMPLES}

The size of the samples used in compressive strength research is unequivocally specified by standards. Normally the compressive strength of the concretes is determined on cube samples $15 \times 15 \times 15 \mathrm{~cm}$ and cylindrical samples $\varnothing 15 \times 30 \mathrm{~cm}$. However in many cases testing on smaller samples is necessary. The research was not analysed in the cases when after certain sample size the effect of the scale decreases without causing any significant drop of the strength. Thus, the research was carried out on cylindrical samples $\varnothing 15 \times 30 \mathrm{~cm}$ and $\varnothing 5,5 \times 11 \mathrm{~cm}$ as well as on cube samples $15 \times 15 \times 15 \mathrm{~cm}$ and $10 \times 10 \times 10 \mathrm{~cm}$. Obtained research results for concrete made on diabase and basalt aggregates are shown in Table 3 and 4.

Table 3. Research results for HPC cylindrical samples of various sizes

\begin{tabular}{|c|c|c|c|c|}
\hline \multirow{2}{*}{ Number } & \multicolumn{2}{|c|}{$\begin{array}{c}\text { Compressive strength of concrete made on } \\
\text { diabase aggregate [MPa] }\end{array}$} & \multicolumn{2}{c|}{$\begin{array}{c}\text { Compressive strength of concrete made on basalt } \\
\text { aggregate [MPa] }\end{array}$} \\
\cline { 2 - 5 } & $\varnothing 15 \times 30 \mathrm{~cm}$ & $\varnothing 5.5 \times 11 \mathrm{~cm}$ & 63.49 & $615 \times 30 \mathrm{~cm}$ \\
\hline 1 & 61.26 & 68.27 & 67.64 & 68.56 \\
\hline 2 & 63.01 & 67.08 & 61.25 & 64.24 \\
\hline 3 & 74.50 & 76.17 & 65.83 & 70.52 \\
\hline 4 & 58.63 & 62.47 & 61.28 & 66.53 \\
\hline 5 & 61.25 & 64.21 & 63.90 & 68.37 \\
\hline $\begin{array}{l}\text { Standard } \\
\text { deviation }\end{array}$ & 63.73 & 67.64 & 2.81 & 2.63 \\
\end{tabular}


Table 4. Research results for HPC cube samples of various sizes

\begin{tabular}{|c|c|c|c|c|}
\hline \multirow{2}{*}{ Number } & \multicolumn{2}{|c|}{$\begin{array}{c}\text { Compressive strength of concrete made on } \\
\text { diabase aggregate [MPa] }\end{array}$} & \multicolumn{2}{c|}{$\begin{array}{c}\text { Compressive strength of concrete made on } \\
\text { basalt aggregate [MPa] }\end{array}$} \\
\cline { 2 - 5 } & $15 \times 15 \times 15 \mathrm{~cm}$ & $10 \times 10 \times 10 \mathrm{~cm}$ & $15 \times 15 \times 15 \mathrm{~cm}$ & $10 \times 10 \times 10 \mathrm{~cm}$ \\
\hline 1 & 68.22 & 67.50 & 84.54 & 88.98 \\
\hline 2 & 72.99 & 72.96 & 88.96 & 83.32 \\
\hline 3 & 72.03 & 73.43 & 86.74 & 86.58 \\
\hline 4 & 69.05 & 71.21 & 82.16 & 85.57 \\
\hline 5 & 71.45 & 71.07 & 84.99 & 86.30 \\
\hline average & 70.75 & 71.23 & 2,86 & 2,07 \\
\hline $\begin{array}{l}\text { Standard } \\
\text { deviation }\end{array}$ & 2,02 & 2,33 & \multicolumn{2}{c}{} \\
\hline
\end{tabular}

a)

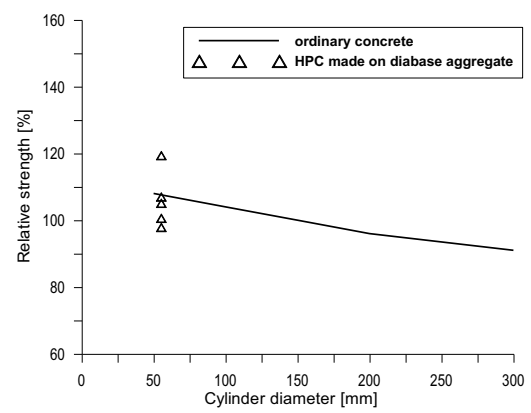

b)

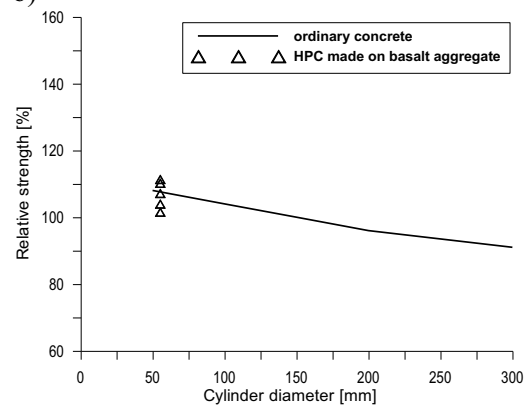

Fig. 4. Impact of the size on apparent strength of cylindrical sample made on ordinary concrete [5] and HPC tested: a) HPC made on diabase aggregate, b) HPC made of basalt aggregate.

a)

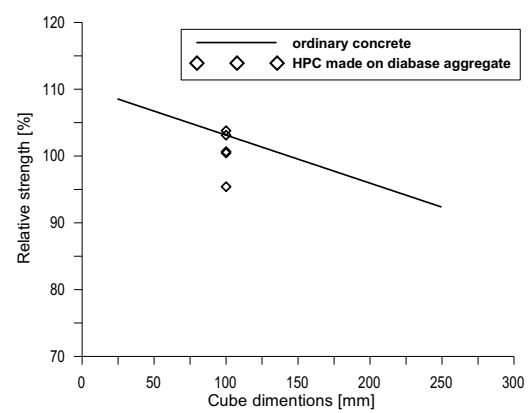

b)

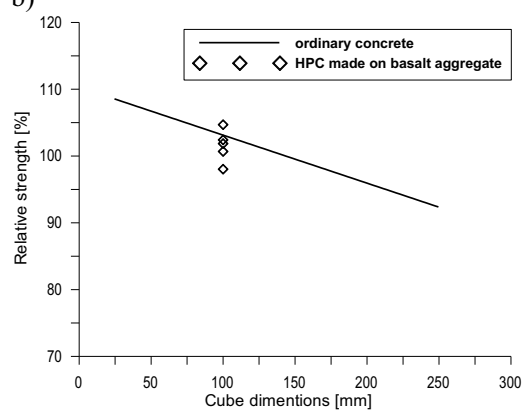

Fig. 5. Impact of the size on apparent strength of cube sample made on ordinary concrete [6] and HPC tested:

a) HPC made on diabase aggregate, b) HPC made on basalt aggregate.

Similarly as in the case of slenderness ratio, the research results carried out on HPC samples of various size indicate smaller differencess in compressive strength than those for ordinary concrete, 
see fig. 4 and 5. Relative strength was determined in relation to adequately defined average strength for cylindrical samples $\varnothing 15 \times 30 \mathrm{~cm}$ and cubes $15 \times 15 \times 15 \mathrm{~cm}$ for different type of HPC.

In the case of high performance concrete compressive strength determined on smaller samples is not significantly different to those determined on samples by standards, it means cube samples $15 \times 15 \times 15 \mathrm{~cm}$ and cylinder samples $\varnothing 15 \times 30 \mathrm{~cm}$. It can be related to the fact that in comparison to ordinary concrete the aggregates with substantially smaller fractions are used in HPC, and it may result i.e. in the wall effect. It should be underlined that the wall effect is more pronounced the larger the surface area to volume ratio of the sample [1].

The cube samples $10 \times 10 \times 10 \mathrm{~cm}$ made on diabase and basalt do not show significant differences in comparison to research carried out on the samples by standards. The differences for the cylindrical samples $\varnothing 5.5 \times 11 \mathrm{~cm}$ of HPC made on diabase were equal approximately $6 \%$ and for samples made on basalt approximately $7 \%$.

Similar to slenderness ratio, cylindrical samples based on diabase, has higher dispersion of strength than concrete made on basalt aggregate. In the case of cube samples, dispersions was comparable.

\subsection{LOAD INCREMENT SPEED}

Load application speed during testing has a significant impact on a receiving strength of concrete. In general, the relation seen in the ordinary concrete shows that the lesser the load increment speed the lesser the strength obtained. Probably, it relates to the increase in the period of deformation as a result of creeping [1]. For the purpose of comparison of the sample results the adequate norms clearly determine the standard speed of the increment of stress during the research. In relation to HPC, described issue may have in terms of structure and smaller deformations more important meaning in comparison to ordinary concrete.

The impact of load application speed research was carried out on the cube samples $15 \times 15 \times 15 \mathrm{~cm}$. The research was carried out at $0.5 \mathrm{MPa} / \mathrm{s}$ standard speed of a load and additionally at $0.05 \mathrm{MPa} / \mathrm{s}$ and 5.0 MPa/s speed. Obtained research results for concrete made on diabase aggregate and basalt aggregate are shown in Table 5 .

According to the research results it can be concluded that the HPC samples tested at speed of 5.0 $\mathrm{MPa} / \mathrm{s}$ have registered a substantially greater increase of the strength than those for ordinary concrete. See fig. 6. As the drawings show, the relative strength for specific type of HPC was determined in relation to average strength obtained on cube samples $15 \times 15 \times 15 \mathrm{~cm}$ and speed of 0.5 $\mathrm{MPa} / \mathrm{s}$. Relative strength of ordinary concrete on figure 6 , was obtained from average of strength at speed of $0,2 \mathrm{MPa} / \mathrm{s}$, which may affect on the results. 
Table 5. The research results of the effect of load application speed to HPC strength

\begin{tabular}{|c|c|c|c|c|c|c|}
\hline \multirow{2}{*}{ Number } & \multicolumn{3}{|c|}{$\begin{array}{c}\text { Compressive strength of concrete made on diabase } \\
\text { aggregate }[\mathrm{MPa}]\end{array}$} & \multicolumn{3}{c|}{$\begin{array}{c}\text { Compressive strength of concrete made on basalt } \\
\text { aggregate [MPa] }\end{array}$} \\
\cline { 2 - 7 } & $0.5[\mathrm{MPa} / \mathrm{s}]$ & $0.05[\mathrm{MPa} / \mathrm{s}]$ & $5.0[\mathrm{MPa} / \mathrm{s}]$ & $0.5[\mathrm{MPa} / \mathrm{s}]$ & $0.05[\mathrm{MPa} / \mathrm{s}]$ & $5.0[\mathrm{MPa} / \mathrm{s}]$ \\
\hline 1 & 68.22 & 80.96 & 84.24 & 84.54 & 75.97 & 98.34 \\
\hline 2 & 72.99 & 79.97 & 83.58 & 88.96 & 78.94 & 102.76 \\
\hline 3 & 72.03 & 72.71 & 90.82 & 86.74 & 77.43 & 95.88 \\
\hline 4 & 69.05 & 67.64 & 93.64 & 82.56 & 72.45 & 99.73 \\
\hline 5 & 71.45 & 66.92 & 91.92 & 82.16 & 74.76 & 96.45 \\
\hline average & 70.75 & 73.64 & 88.84 & 84.99 & 75.91 & 98.63 \\
\hline $\begin{array}{c}\text { Standard } \\
\text { deviation }\end{array}$ & 2,05 & 6,62 & 4,62 & 2,86 & 2,49 & 2,77 \\
\hline
\end{tabular}

For the samples made on diabase and tested at speed of $5.0 \mathrm{MPa} / \mathrm{s}$ the strength increase of approximately $25 \%$ was obtained in relation to samples tested at standard speed. The differences achieved for samples made on basalt were around $16 \%$. In both cases the differences are greater than in the case of ordinary concrete.

Testing at speed of $0.05 \mathrm{MPa} / \mathrm{s}$ gave divergent results for each HPC concrete. HPC made on base of diabase indicated a minimal increase of strength (approximately 4\%) in relation to tests carried out at standard speed. On the other hand, for HPC made on basalt a greater decline of the strength was achieved than in the case of ordinary concrete. Registered occurrence seems to be difficult to explain, although, it may result from the properties of applied aggregate, and as mentioned above from the different deformation properties of HPC than in the case of ordinary concrete.

a)

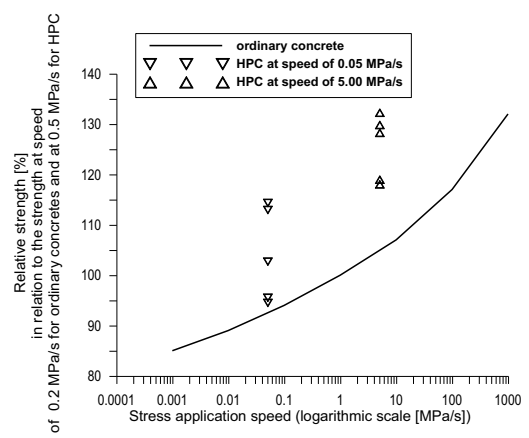

b)

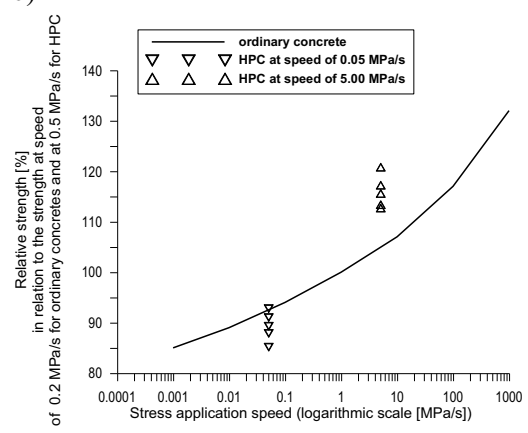

Fig. 6. The effect of load application speed on the apparent strength of cube sample made on ordinary concrete [7] and HPC tested: a) HPC made on diabase aggregate, b) HPC made on basalt aggregate. 


\section{THE GENERAL DESCRIPTION OF THE RESEARCH}

During the compressive strength determination high performance concrete, in terms of their characteristics, indicate divergent behavior than the ordinary concrete. The research performed shows that the slenderness ratio has a greater effect in low performance concrete. It should be underline that the effect of the slenderness ratio disappears in the case of eliminating the friction on the surface area - uniaxial state of stress. It needs to be remembered that values of correction factors regarding the effect of the slenderness ratio of tested samples also depend on strength values of concrete.

The compressive strength determined for high performance concrete on smaller samples does not significantly differ from those determined on samples by standards. It may result from the minimisation of the scale effect in HPC in comparison to ordinary concretes. During the carried out research, the usage of smaller samples in HPC strength research may appear to be important in regards to the required pressure force.

„Small” samples testing, can also be useful for assessment of technical condition of the objects made of HPC. It is associated with the necessity of cores taking, used to determine the current strength of concrete. Knowledge about the correlations between different samples allow the correct assessment of the strength of HPC.

The results obtained during testing of the HPC strength confirm a significant effect of the increment stress speed. Mainly, it applies to all research with speed of the stress greater than the set norms. The increase in strength recorded in HPC is greater than in ordinary concrete. This can have a significant impact during strength analysis of high performance concrete under influence of exceptional load. Knowledge of the HPC behavior in different load conditions may result in its wider use, and in the case of civil engineering a significant change of the approach to design and construction of underground objects, which often are subjected to dynamic loads coming from mining tremors. Knowledge of the behavior of HPC under such influences, can result in its wider use. 


\section{REFERENCES}

1. A. M. Neville, "Właściwości betonu”. Stowarzyszenie Producentów Cementu, Kraków, 2000.

2. P. Czaja, J. Hydzik, and D. Wałach, „Ekonomiczne aspekty stosowania betonu wysokowartościowego w budownictwie podziemnym". Górnictwo i Geoinżynieria. 33/3/1, 2009, p. 121-130.

3. J. W. Murdock, and C.E. Kelser, Effect of length to diameter ratio of specimen on the apparent compressive strength of concrete. ASTM Bull.,1957, p. 68-73.

4. H. F. Gonnerman, "Effect of size and shape of test specimen on compressive strength of concrete". Proc. ASTM. 25, Part II, 1925, p. 237-250.

5. R. F. Blanks, and C. C. Mc. Namara, "Mass concrete test in large cylinders.” J. Amar. Concr. Inst. 31, 1935, p. 280-303.

6. A.M. Neville, "Some aspects of the strengths of concrete", Civil Engineering (London), 54, Part 1, p. 1153-5 (Oct. 1959); Part 2, p. 1308-11 (Nov. 1959); Part 3, p. 1435-9 (Dec. 1959).

7. D. McHenry and J.J. Shideler, "Review of data on effect of speed in mechanical testing of concrete", ASTM Sp. Tech. Publ.. Nr 185, 1956, p. 72-82.

\section{LIST OF FIGURES AND TABLES:}

Fig. 1. Results of sieve analysis of used aggregates

Rys. 1. Wyniki analizy sitowej zastosowanych kruszyw

Fig. 2. Impact of height-diameter of the cylinder relation to the apparent strength of cylindrical sample made on ordinary concrete [4] and HPC tested: a) HPC made on diabase aggregate, b) HPC made on basalt aggregate.

Rys. 2. Wpływ stosunku wysokości walca do jego średnicy na wytrzymałość pozorną próbki walcowej wykonanej z betonu zwykłego [4] i badanego BWW: a) BWW na kruszywie z diabazu, b) BWW na kruszywie $\mathrm{z}$ bazaltu.

Fig. 3. Effect of height-diameter relation to the apparent strength of cylindrical samples made on ordinary concrete of various strength [3] and HPC tested: a) HPC made on diabase aggregate, b) HPC made on basalt aggregate.

Rys. 3. Wpływ stosunku wysokości do średnicy na wytrzymałość pozorną próbki walcowej wykonanej z betonu zwykłego o różnych wytrzymałościach [3] i badanego BWW: a) BWW na kruszywie z diabazu, b) BWW na kruszywie $\mathrm{z}$ bazaltu.

Fig. 4. Impact of the size on apparent strength of cylindrical sample made on ordinary concrete [5] and HPC tested: a) HPC made on diabase aggregate, b) HPC made of basalt aggregate.

Rys. 4. Wpływ wielkości na wytrzymałość pozorną próbki walcowej wykonanej z betonu zwykłego [5] i badanego BWW: a) BWW na kruszywie z diabazu, b) BWW na kruszywie z bazaltu. 
Fig. 5. Impact of the size on apparent strength of cube sample made on ordinary concrete [6] and HPC tested: a) HPC made on diabase aggregate, b) HPC made on basalt aggregate.

Rys. 5. Wpływ wielkości na wytrzymałość pozorną próbki kostkowej wykonanej z betonu zwykłego [6] i badanego BWW: a) BWW na kruszywie z diabazu, b) BWW na kruszywie z bazaltu.

Fig. 6. The effect of load application speed on the apparent strength of cube sample made on ordinary concrete [7] and HPC tested: a) HPC made on diabase aggregate, b) HPC made on basalt aggregate. Rys. 6. Wpływ prędkości przykładania obciążenia na wytrzymałość pozorną próbki kostkowej wykonanej z betonu zwykłego [7] i badanego BWW: a) BWW na kruszywie z diabazu, b) BWW na kruszywie z bazaltu.

Tab. 1. Concrete mixture composition

Tab. 1. Skład mieszanek betonowych

Tab. 2. Research results of slenderness ratio for HPC samples

Tab. 2. Wyniki badań próbek BWW o różnych smukłościach

Tab. 3. Research results for HPC cylindrical samples of various sizes

Tab. 3. Wyniki badań walcowych próbek BWW o różnych wielkościach

Tab. 4. Research results for HPC cube samples of various sizes

Tab. 4. Wyniki badań kostkowych próbek BWW o różnych wielkościach

Tab. 5. The research results of the effect of load application speed to HPC strength

Tab. 5. Wyniki badań wpływu prędkości przykładania obciążenia na wytrzymałość BWW 


\section{WPLYW WARUNKÓW BADANIA NA PARAMETRY WYTRZYMALOŚCIOWE BETONÓW WYSOKOWARTOŚCIOWYCH}

Slowa kluczowe: beton wysokowartościowy, budownictwo, wysoka wytrzymałość

\section{STRESZCZENIE:}

Postęp technologiczny spowodował znaczący rozwój produkcji betonu. Możliwość realizacji wielu obiektów, wymaga stosowania betonów o coraz bardziej specjalistycznych właściwościach a tym samym stosowanie mieszanek o coraz to wyższych wytrzymałościach. Odpowiedzią na te rosnące wymagania dzisiejszego budownictwa, może okazać się beton wysokowartościowy, który w ostatnim czasie znajduje coraz szersze zastosowanie. Określane parametry wytrzymałościowe betonów w istotny sposób zależą od warunków prowadzonych badań. Dotyczy to zarówno wielkości samych próbek badawczych jak i m.in. prędkości obciążania. Zagadnienia te w odniesieniu do betonów zwykłych są powszechnie znane, jednak w przypadku betonów wysokowartościowych, które ostatnio znajdują coraz powszechniejsze zastosowanie, uzyskuje się nieco odmienne wyniki badanych parametrów wytrzymałościowych niż w przypadku betonów zwykłych. Znajomość tych zagadnień może w istotny sposób wpływać m.in. na interpretację prowadzonych badań diagnostycznych elementów wykonanych z BWW.

W artykule przedstawiono wyniki badań parametrów wytrzymałościowych BWW określonych przy różnych warunkach. Dla porównania uzyskane wyniki odniesiono do zależności znanych w betonach zwykłych.

Uzyskane wyniki badań wykazały, że w przypadku BWW różnice wytrzymałości na ściskanie określane na próbkach o różnych smukłościach są zdecydowanie mniejsze niż w przypadku betonów zwykłych. Otrzymane wyniki badań potwierdzają teorię Murdocka i Keslera, że wartości współczynników poprawkowych zależą również od wartości wytrzymałości betonu. Wytrzymałość BWW jest zatem mniej podatna na zmiany proporcji próbki badawczej oraz jest mniej zależna od kształtu samej próbki. Można również zauważyć, że badane betony wysokowartościowe, dla których uzyskano średnie wytrzymałości na ściskanie na poziomie 63,73 MPa i 63,90 MPa w zadawalający sposób wpisują się w zależności określone przez Murdocka i Keslera dla betonów wyższych klas. Z powyższych rozważań wynika, że w przypadku betonów wysokowartościowych wytrzymałość na ściskanie określana na próbkach o smukłościach mniejszych niż 2, nie odbiega znacząco od tych, określanych na próbkach normowych o stosunku h/d = 2 .

Przeprowadzone badania wykazały, że w przypadku betonów wysokowartościowych wytrzymałość na ściskanie określana na mniejszych próbkach, nie odbiega znacząco od tych, określanych na próbkach normowych, czyli na próbkach kostkowych $15 \times 15 \times 15 \mathrm{~cm}$ i walcach $\varnothing 15 \times 30 \mathrm{~cm}$. Może to być związane $\mathrm{z}$ faktem, iż w BWW stosuje się kruszywa o znacznie mniejszych frakcjach w porównaniu do betonów zwykłych, co może wpływać m.in. na efekt ściany. Należy podkreślić, że efekt ściany jest tym wyraźniejszy, im większy jest stosunek powierzchni do objętości próbki.

W przypadku badanych próbek kostkowych $10 \times 10 \times 10 \mathrm{~cm}$ wykonanych zarówno na diabazie jak i bazalcie, nie zarejestrowano istotnych różnic wytrzymałości w porównaniu do badań wykonanych na próbkach normowych. W przypadku próbek walcowych $\varnothing 5,5 \times 11 \mathrm{~cm}$ różnice te wyniosły ok. $6 \%$ dla BWW wykonanego na diabazie oraz ok. $7 \%$ dla próbek wykonanych na bazalcie.

Na podstawie uzyskanych wyników badań można stwierdzić, że w badanych BWW zarejestrowano znacznie wyższy wzrost wytrzymałości przy badaniu z prędkością 5,0 $\mathrm{MPa} / \mathrm{s}$ niż w przypadku betonów zwykłych. Dla próbek wykonanych na diabazie i badanych z prędkością 5,0 MPa/s uzyskano średnio $25 \%$ wzrost wytrzymałości w stosunku 
do próbek badanych z prędkością normową. Dla próbek wykonanych na bazalcie różnice te wyniosły ok. $16 \%$. Zarówno w jednym jak i w drugim przypadku różnice te są znacząco większe niż w przypadku betonów zwykłych. Podsumowując można stwierdzić, że betony wysokowartościowe, ze względu na swoje własności, wykazują istotnie odmienne zachowanie niż betony zwykłe podczas określania ich wytrzymałości na ściskanie. Z przeprowadzonych badań wynika, że smukłość próbki ma większy wpływ w betonach o niższej wytrzymałości. Należy podkreślić, że wpływ smukłości zanika w przypadku wyeliminowania tarcia na powierzchniach czołowych - jednoosiowy stan naprężenia. Należy także pamiętać, że wartości współczynników poprawkowych uwzględniających wpływ smukłości badanych próbek zależą również od wartości wytrzymałości betonu.

W przypadku betonów wysokowartościowych wytrzymałość na ściskanie określana na mniejszych próbkach, nie odbiega znacząco od tych, określanych na próbkach normowych. Może to wynikać, z minimalizacji efektu skali w BWW w porównaniu do betonów zwykłych. Stosowanie mniejszych próbek do badań wytrzymałościowych BWW może okazać się istotne ze względu na wymagane siły nacisku podczas badań tych betonów.

Uzyskane wyniki badań potwierdzają istotny wpływ szybkości przyrosty naprężeń podczas badań wytrzymałościowych BWW. Dotyczy to przede wszystkich badań z prędkościami obciążenia większymi niż normowe. W BWW rejestruje się znacznie wyższy wzrost wytrzymałości niż w przypadku betonów zwykłych. Może mieć to istotny wpływ w przypadku analizy wytrzymałości betonów wysokowartościowych pod wpływem działania obciążeń wyjątkowych. 
